\title{
Kajian Kandungan Kimia Darah Dan Pertambahan Bobot Badan Domba Garut Betina Lepas Sapih Dengan Imbangan Protein Dan Energi Yang Berbeda
}

\author{
F. Faisal ${ }^{1 \mathrm{a}}$, A. Rochana ${ }^{1}$ dan K. A. Kamil ${ }^{1}$ \\ ${ }^{I}$ Departemen Nutrisi Ternak dan Teknologi Pakan Fakultas Peternakan Universitas Padjadjaran \\ a email:ferryfapet@gmail.com
}

\begin{abstract}
Abstrak
Domba Garut betina merupakan salah satu jenis domba yang bisa dijadikan sebagai penghasil daging untuk memenuhi kebutuhan protein hewani masyarakat di Indonesia. Domba Garut memiliki beberapa keunggulan yakni tahan terhadap manajemen pemeliharaan yang kurang baik. Penelitian mengenai kajian kandungan kimia darah dan pertambahan bobot badan domba garut betina lepas sapih yang diberi imbangan protein dan energi yang berbeda telah dilaksanakan pada bulan Mei sampai dengan Juni 2017 di Balai Pengembangan Pembibitan Ternak Domba, Margawati Kabupaten Garut. Ternak yang digunakan dalam penelitian ini adalah domba Garut betina umur rata-rata 4-5 bulan sebanyak 24 ekor dengan bobot awal rata-rata 10,24 Kg $\pm 1,05 \mathrm{Kg}$. Rancangan percobaan yang digunakan dalam penelitian ini adalah Rancangan Acak Lengkap dengan 6 perlakuan imbangan protein dan energi yaitu $\mathrm{R} 1=12 \%$ dan $60 \%$, R $2=12 \%$ dan $65 \%$, R3 $=14 \%$ dan $60 \%$, R $4=14 \%$ dan $65 \%$, R5 $=16 \%$ dan $60 \%$, R6 $=16 \%$ dan $65 \%$. Peubah yang diamati meliputi kandungan kimia darah (Kolesterol, High density lipoprotein, Low density lipoprotein, Glukosa, Trigliserida) dan Pertambahan Bobot Badan. Data yang diperoleh dianalisis dengan menggunakan Anova. Hasil pengamatan menunjukan bahwa pemberian pakan dengan imbangan protein dan energi yang berbeda pada domba Garut betina lepas sapih tidak memberikan pengaruh yang nyata $(\mathrm{P}>0,05)$ terhadap kandungan Kolesterol, HDL, LDL, glukosa, dan trigliserida. Perbedaan imbangan protein dan energi dalam ransum tidak mempengaruhi pertambahan bobot badan domba garut. Kesimpulan, Pada level protein $12 \%$ dan energi $60 \%$ menghasilkan kandungan kimia darah dan pertambahan bobot badan optimal.

Kata Kunci: Domba Garut Betina, Protein, Energi, Kimia Darah, Pertambahan Bobot Badan

\section{Study Of Chemical Blood And Average Daily Gain Of Female Garut Sheep With Different Ratio Protein And Energy}

Abstract

Female arut sheep is a type of sheep that can be used as a meat producer to meet the needs of animal protein for communities in Indonesia. Garut sheep has several advantages which is more resistant to low maintenance management. The research about the effect of protein and energy ratio in complete ration on lipid in the blood and average of daily weight gain of female garut sheep had conducted from May until June 2017 at the UPTD BPPT Margawati Garut. This study used 24 Garut ewes aged 4-5 months with body weight of $10.24 \pm 1,05 \mathrm{Kg}$. This research used experimental method with a completely randomized design with 6 treatments of the ratio protein to energy $R I=12 \%$ and $60 \%$, $R 2=12 \%$ and $65 \%, R 3=14 \%$ and $60 \%, R 4=14 \%$ and $65 \%, R 5=16 \%$ and $60 \%, R 6=16 \%$ and $65 \%$. Each treatment was repeated four times with the observed variables were lipid in the blood (Cholesterol, HDL, LDL Glucose, Protein, Triglycerides) and average of daily weight gain. The data were analyzed with ANOVA test. The result showed that different ratio of protein and energy in the ration of female garut sheep of this study did not give any effect on lipid in the blood and average of daily weight gain $(P>0.05)$. In conclution, Ratio protein $12 \%$ and energy $60 \%$ gave highest average weight gain and chemical blood.
\end{abstract}

Key Word: Female garut sheep, Protein, Energy, Blood Lipid, Weight Gain 


\section{Pendahuluan}

Penyediaan protein hewani untuk memenuhi kebutuhan masyarakat belum sepenuhnya terpenuhi, karena pertambahan penduduk yang lebih cepat daripada peningkatan produksi pangan asal hewani khususnya dalam penyediaan daging domba. Pada saat ini produksi daging domba hanya 48,074 Ton per tahun di Indonesia (Direktorat Jendral Peternakan, 2016). Jumlah penduduk Indonesia pada tahun 2010 saja sudah mencapai 237.641.326 jiwa (BPS, 2010). Meningkatnya kebutuhan konsumsi daging sebagai manifestasi peningkatan taraf hidup dan pengetahuan, menyebabkan perubahan pola konsumsi masyarakat ke arah yang lebih baik. Hal tersebut harus selaras dengan peningkatan permintaan jumlah protein hewani yang berasal dari daging domba.

Terdapat permasalahan dalam keberlangsungan pemeliharaan domba salah satunya yaitu produktivitas tidak optimal dikarenakan kualitas nutrisi yang terbatas Rendahnya protein pada pakan memberikan efek negatif terhadap kekebalan tubuh dan produksi ternak (Sahoo et al., 2002 dalam Sahoo et al., 2009). Profil lipid dalam darah merupakan salah satu parameter yang bisa digunakan untuk mengetahui kondisi kesehatan dan produktivitas ternak.Darah memiliki peran yang kompleks dalam proses fisiologis tubuh (Gross et al., 2016). Fungsi darah dalam tubuh adalah sebagai alat transportasi nutrien, mengangkut sisa metabolisme, transportasi hormon yang dihasilkan kelenjar endokrin (Frandson, 1992). Hipotesis pada penelitian ini adalah pemberian imbangan protein dan energi $16 \%$ dan energi $65 \%$ diharapkan memberikan hasil yang paling optimal terhadap komposisi kimia darah dan pertambahan bobot badan domba garut betina lepas sapih.

\section{Materi dan Metode}

Penelitian telah dilaksanakan di UPTD

Balai Pengembangan dan Perbibitan Ternak Domba dan Kambing Margawati, Garut. Penelitian dilakukan secara eksperimental menggunakan rancangan acak lengkap, ternak percobaan yang digunakan untuk penelitian adalah domba Garut betina lepas sapih berumur rata-rata 4-5 bulan sebanyak 24 ekor. Adaptasi dilakukan selama dua minggu, kemudian ternak diberikan perlakuan pemberian pakan selama 2 bulan. Domba diberi pakan berupa rumput dan konsentrat yang dibuat dari campuran dedak, ampas kecap, onggok, bungkil kelapa, premix.

Pada awal penelitian, bobot rata-rata domba betina lepas sapih adalah $10.74 \mathrm{Kg}$ $\pm 1,05 \mathrm{Kg}$. Ternak domba dimasukan ke dalam kandang individu. Pada setiap kandang penelitian diberi nomor sesuai dengan perlakuan. Ternak domba diberi perlakuan pakan dengan 6 imbangan protein dan energi yang berbeda, yaitu R1 $12 \%$ dan $60 \%$, R2 $12 \%$ dan $65 \%$, R3 $14 \%$ dan $60 \%$, R4 $14 \%$ dan $65 \%$, R5 $16 \%$ dan $60 \%$, R6 $16 \%$ dan 65 $\%$. Pengambilan sampel darah dilakukan pada pagi hari, setelah domba di puasakan dan penimbangan bobot badan domba dilakukan setiap satu minggu sekali. Parameter yang diuji yaitu kolesterol, trigliserida, glukosa, High Density Lipoprotein, Low Density Lipoprotein, Protein Total dan Pertambahan Bobot Badan. Data yang terkumpul dianalisis menggunakan uji anova dan dilanjutkan menggunakan uji Duncan (Steel dan Torrie, 1993). Analisis data dilakukan dengan menggunkan software SPSS.

\section{Hasil dan Pembahasan \\ Kandungan lipid dalam Darah}

Pengaruh pemberian pakan dengan imbangan protein dan energi yang berbeda tersaji pada tabel 3. Hasil penelitian ini menunjukkan bahwa Perbedaan pemberian jumlah imbangan protein dan energi dalam ransum domba Garut betina tidak mempengaruhi kandungan lipid dalam darah dan peningkatan bobot badan harian secara signifikan

Hasil yang tidak signifikan pada kandungan kimia darah diduga karena tekstur dan bau pakan yang berbeda-beda sehingga konsumsi pakan yang hampir sama pada setiap perlakuan meskipun pakan diberikan berdasarkan bobot badan domba. Bau dan tekstur pakan akan mengganggu palatabilitas dan berpengaruh terhadap konsumsi ransum (Sudarman dkk. 2008). Hal lain yang diduga mempengaruhi kandungan kimia darah menjadi tidak signifikan adalah stres akibat penimbangan yang dilakukan seminggu sekali sehingga sistem metabolisme tubuh domba menjadi terganggu. Proses metabolisme dalam tubuh domba berperan mengubah zat makanan menjadi senyawa yang diperlukan untuk proses kehidupan domba seperti glukosa, trigliserida, kolesterol dan lain-lain. 
Tabel 1. Pengaruh perlakuan terhadap kandungan kimia darah dan pertambahan bobot badan

\begin{tabular}{|c|c|c|c|c|c|c|}
\hline \multirow[t]{2}{*}{ Peubah } & \multicolumn{6}{|c|}{ Perlakuan } \\
\hline & $\mathrm{R} 1$ & $\mathrm{R} 2$ & R3 & R4 & R5 & R6 \\
\hline Glukosa (mg/dL) & $67,25 \pm 6,4$ & $57,25 \pm 9,1$ & $64,75 \pm 3,1$ & $55,5 \pm 14,1$ & $51,75 \pm 7,4$ & $68 \pm 6,5$ \\
\hline Trigliserida (mg/ dL) & $38,5 \pm 7,8$ & $45 \pm 11,8$ & $61,5 \pm 14,4$ & $48 \pm 9,8$ & $47,25 \pm 11,9$ & $31 \pm 3,6$ \\
\hline Kolesterol (mg/ dL) & $43,25 \pm 13,4$ & $68,5 \pm 14,9$ & $63,5 \pm 14$ & $60,75 \pm 15$ & $58,25 \pm 14,4$ & $31 \pm 14,6$ \\
\hline Protein Total (g/ dL ) & $4,7 \pm 1,1$ & $5,92 \pm 0,4$ & $6,05 \pm 1,4$ & $6,12 \pm 0,9$ & $5,85 \pm 0,4$ & $5,47 \pm 1,3$ \\
\hline $\begin{array}{l}\text { High Density } \\
\text { Lipoprotein }(\mathrm{mg} / \mathrm{dL})\end{array}$ & $23,5 \pm 4,5$ & $46,25 \pm 6,2$ & $39,25 \pm 6,5$ & $38,25 \pm 6,8$ & $36,75 \pm 6,2$ & $22,25 \pm 6$ \\
\hline $\begin{array}{l}\text { Low Density } \\
\text { Lipoprotein (mg/dl) } \\
\text { Pertambahan Bobot }\end{array}$ & $15,5 \pm 9,1$ & $13,25 \pm 6,7$ & $12,00 \pm 4,5$ & $12,75 \pm 5,2$ & $12,00 \pm 5$ & $11,00 \pm 2,9$ \\
\hline Badan (g/hari) & $34,75 \pm 10,24$ & $29,5 \pm 9,11$ & $31,25 \pm 9,74$ & $33,75 \pm 2,21$ & $28 \pm 12,09$ & $20 \pm 10,93$ \\
\hline
\end{tabular}

Kolesterol total sebenarnya merupakan susunan dari banyak zat termasuk trigliserida, low density lipoprotein (LDL), high density lipoprotein (HDL) (Ogata, 2010). Kolesterol yang terdapat pada LDL ditangkap oleh reseptor khusus dijaringan perifer. Kelebihan kolesterol dalam jaringan perifer diangkut oleh HDL ke dalam hati untuk dikeluarkan melalui saluran empedu sebagai asam empedu (Cheng dan Hardy, 2004). Kandungan kolesterol pada perlakuan ini adalah $31 \mathrm{mg} / \mathrm{dl}-68,5 \mathrm{mg} / \mathrm{dL}$ hasil ini menunjukan kandungan kolesterol hampir sama dengan penelitian Gagah (2016) yaitu antara $58 \mathrm{mg} / \mathrm{dL}-81 \mathrm{mg} / \mathrm{dL}$.

High Density Lipoprotein (HDL) mempunyai fungsi penting dalam mengikat kelebihan kolesterol beserta dan mengangkutnya bersama aliran darah menuju ke sel-sel hati .Kadar Hdl yang tinggi mencegah terjadinya resiko ateroklerosis dengan cara mengangkut kolesterol dari jaringan perifer menuju hati. Kandungan Hdl pada penelitian ini $22,25-46,25 \mathrm{mg} / \mathrm{dL}$.

Low Density Lipoprotein (LDL) merupakan kelas lipoprotein yang tersusun atas protein, trigliserida, kolesterol dan fosfolipid dimana kolesterol merupakan penyusun terbesar. Salah satu cara untuk menurunkan kolesterol dalam darah adalah dengan memperbesar pengeluaran kolesterol bersama-sama dengan asam empedu, kolesterol yang hilang tersebut tergantung pada kandungan lemak pakan. Hal ini sesuai pendapat Santoso (2002) menyatakan bahwa kandungan lemak pakan berkaitan langsung dengan peningkatan atau penurunan lemak dalam darah. Kandungan LDL darah pada penelitian ini adalah $11-15,5 \mathrm{mg} / \mathrm{dL}$. Kandungan ini lebih kecil dibandingkan dengan nilai HDL22,25 - 46,25. LDL sering disebut lemak jahat sehingga kandungannya harus lebih rendah dibandingkan HDL.

Kandungan trigliserida darah pada penelitian iniberkisar antara $31 \mathrm{mg} / \mathrm{dl}-61,5$ $\mathrm{mg} / \mathrm{dl}$. Hasil ini menunjukan bahwa kandungan trigliserida domba betina lepas sapih lebih tinggi dari penelitian Jeffri (2015) yaitu $26,62 \mathrm{mg} / \mathrm{dl}$. Hal ini diduga karena pakan yang dikonsumsi mengandung nutrisi yang baik sehingga menghasilkan nilai trigliserida yang lebih tinggi. Kandungan lipid dalam darah pada ternak ruminansia ataupun ternak monogastrik dipengaruhi oleh asupan pakan yang diberikan (Gagah, 2016)

Kandungan protein total dalam darah domba pada penelitian ini adalah $4,7 \mathrm{~g} / \mathrm{dL}-$ $6,1 \mathrm{~g} / \mathrm{dL}$. Kandungan protein pada penelitian ini cenderung lebih rendah apabila dibandingkan dengan hasil penelitan Gagah dkk (2016) yaitu 7,32 g/dL. Total protein darah pada penelitian ini masih dalam kisaran normal sesuai laporan Cynthia dan Scott (2005) yaitu $5,90-7,8 \mathrm{~g} / \mathrm{dL}$. Hal ini diduga karena protein pakan sebagian dipecah dalam rumen oleh mikroba menjadi asam amino dan peptida serta sebagian protein yang tidak mengalami fermentasi diserap langsung oleh usus, asam amino yang berlebih dibawa ke hati dan diubah menjadi amonia. Soeparno (2005) menyatakan bahwa protein yang masuk ke dalam tubuh akan mengalami tiga kemungkinan yaitu dicerna oleh mikroba rumen, mengalami degradasi, dan diserap 
melalui dinding rumen lalu di bawa menuju hati, diubah menjadi urea dan kemungkinan lain yaitu protein melalui rumen tanpa mengalami degradasi. Pada ternak muda protein yang diabsorbsi dimanfaatkan oleh tubuh ternak untuk pertumbuhan, mengganti sel-sel yang rusak dan pada kondisi tertentu akan diubah menjadi energi.Kandungan glukosa darah domba adalah $51,75 \mathrm{mg} / \mathrm{dL}-68$ $\mathrm{mg} / \mathrm{dL}$. Kadar glukosa darah ini masih masuk dalam kisaran normal. Menurut Chyntia (2005) nilai normal glukosa darah domba adalah $44-81 \mathrm{mg} / \mathrm{dL}$, sementara itu apabila dibandingkan dengan hasil penelitian Astuti dan Suprayogi (2005) kandungan glukosa darah pada penelitian ini masih lebih tinggi yakni 37 - $59 \mathrm{mg} / \mathrm{dL}$. Hasil penelitian Antunovic dkk. (2001) dalam Wijaya (2016) menyatakan bahwa pakan yang diberikan pakan sesuai kebutuhan akan menghasilkan kandungan metabolik yang normal namun apabila pakan yang diberikan kurang maka nilai metabolik darah akan rendah (Ogata dkk, 2010).

\section{Pertambahan Bobot Badan}

Pada penelitian ini, pertambahan bobot badan domba berkisar antara $20-34,75$ $\mathrm{g} /$ hari, lebih kecil dari hasil penelitian Maulidina (2011) Pemberian level protein 14 $\%$ dan Energi masing 65, 70 dan $75 \%$ pada domba jantan lepas sapih menghasilkan pertambahan bobot badan sebesar $62 \mathrm{~g} / \mathrm{hr}, 70$ $\mathrm{g} / \mathrm{hr}$ dan $82 \mathrm{~g} / \mathrm{hr}$. Penelitian lain dari martawidjaja (1999) pertambahan bobot badan kambing betina muda yang diberi pakan dengan imbangan protein $12 \%$ dan energi 3,5 $\mathrm{mkal} / \mathrm{kg}$ menghasilkan pertambahan bobot sebesar $54 \mathrm{gr} / \mathrm{hr}$. Pertambahan bobot badan domba dipengaruhi jenis pakan, bangsa domba, umur, kondisi lingkungan dan manajemen pemeliharaan (NRC, 2007). Sejalan dengan pernyataan Sahoo (2009) bahwa laju pertumbuhan dipengaruhi oleh umur, lingkungan dan genetik penelitian yang menunjukan tidak berbeda nyata dapat disebabkan oleh umur ternak domba yang masih dalam pertumbuhan tulang sehingga menghasil pertambahan bobot badan yang tidak signifikan.Faktor lain yang menyebabkan hasil tidak berbeda nyata adalah konsumsi pakan yang hampir sama pada tiap perlakuan. Hasnudi dan Wahyuni (2005) menyatakan bahwa PBB yang tidak berbeda nyata dapat disebabkan ternak domba mengkonsumsi pakan yang jumlahnya tidak berbeda nyata.

Faktor lain yang diduga mempengaruhi pertumbuhan adalah jumlah kelahiran anak. Tingginya pertumbuhan kambing/domba anak satu diduga karena kecukupan air susu dari induk lebih terjamin. Menurut Adriani, dkk., (2003) bahwa pertumbuhan anak kambing/domba lepas sapih sangat tergantung pada kecukupan air susu yang diberikan induk kepada anak. Kondisi ternak pada saat masa menyusui menjadi hal yang penting dalam pertumbuhan karena kecukupan nutrisi ternak pada saat disapih akan menjadi faktor penentu pertumbuhan ternak. Domba betina yang digunakan dalam penelitian ini merupakan hasil seleksi dari induk dengan jumlah kelahiran anak yang berbeda-beda.

\section{Kesimpulan}

Pemberian ransum dengan imbangan protein dan energi yang berbeda-beda tidak memberikan pengaruh yang nyata terhadap kandungan lipid dalam darah dan pertambahan bobot badan domba betina lepas sapih. Imbangan protein $12 \%$ dan energi $60 \%$ memberikan jumlah tertinggi terhadap pertambahan bobot badan domba Garut betina lepas sapih pada penelitian ini.

\section{Daftar Pustaka}

Astuti, D., A.Suprayogi, D.R. Marwah dan Suryani. 2006. Status Nutrien dan Gambaran Darah Domba Lokal yang Dipelihara di Hutan Pendidikan Gunung Walat Sukabumi. Seminar Nasional Teknologi Peternakan dan Veteriner. Fakultas Peternakan. Institut Pertanian Bogor.

Badan Pusat Statistik. 2010. Populasi masyarakat indonesia. https://www.bps.go.id/linkTableDinami s/view/id/1024. diakses pada 10 oktober 2017.

Cheng ZJ., and R.W Hardy . 2004. Protein and lipid sources affect cholesterol concentrations of juvenile Pacific white shrimp, Litopenaeus vannamei (Boone). $J$ Animal Science 82(4):1136-1145.

Cynthia M. K, dan Scott L (Ed). 2005. The Merck Veterinary Manual. 9th ed. New Jersey (US): Kahn CM Merck \& Co Inc.

Direktorat Jenderal Peternakan. 2016. Produksi Daging (ton), 2010 - 2015 
[Online]. Tersedia : http://www.bps.go.id/linkTabelStatis/vie w/id/1506. Diakses Tanggal 29 Januari 2017.

Frandson, R. D. 1992. Anatomi dan Fisiologi Ternak Edisi keempat. Gadjah Mada University Press. Yogyakarta.

Gagah, H.W., M. Yamin., H. Nuraini, dan A. Esfandiari 2016. Performans Produksi dan Profil Metabolik Darah Domba Garut dan Jonggol yang Diberi Limbah Tauge dan Omega-3. Jurnal Veteriner. No. 2 :246-256.

Gross, J. J., A.C. Schwinn, F.Schmitz-Hsu, F. Menzi, C. Drogemuller, C. Albrecht, and R. M. Bruckmaier. 2016. Rapid Communiation:Cholesterol Deficiencyassociated $A P O B$ Impacts Lipid Metabolism In Holstein Calves and Breedingbulls. J. Anim. Sci. 94:17611766.

Jeffri, P. A. 2015. Konsumsi Nutrien dan Gambaran Metabolit Darah Domba Prasapih yang diberi Milk Replacer Mengandung Tepung Jangkrik atau Pipa Ulat Sutra. Skripsi Fakultas Peternakan. Institut Pertanian Bogor.

Maulidina, A. 2011. Hubungan Level Energi Ransum Dengan Percepatan Perkawinan Calon Induk Domba Lokal. Fakultas Peternakan. Institut Pertanian Bogor.
Martawidjaja, M., B. Setiadi, and Sorta S. Sitorus. 1999. The effect of proteinenergy levels dietary on Kacang goats performances. Jurnal Ilmu Ternak dan Veteriner 4(3): 167-172.

NRC. 2007. Nutrient Requirements of Sheep. Edisi 6. National Academy Press. Washington. USA.

Ogata, Y., M. K. Alam, Y. Sako, M. AlMamun and H. Sano. 2010. Intermediary Metabolism of Plasma Acetic Acid, Glucose and Protein in Sheep Fed a Rice Straw-based Diet. Iwate University. Morioko, Japan

Sahoo, A., A. K. Pattanaik, and T. K. Goswami. 2009. Immunobiochemical Status of Sheep Exposed to Periods of Experimental Protein deficit and Realimentation. J.Anim. Sci. 87:26642673.

Soeparno. 2005. Ilmu dan Teknologi Daging. Gadjah Mada University. Yogyakarta. 1 - 40 ; 283.

Sudarman A., K. G. Wiryawan dan H. Markhamah. 2008. Penambahan sabunkalsium dari minyak ikan lemuru dalam ransum: 1. Pengaruhnya terhadap tampilan produksi domba. Media Peternakan, Vol. 31 (3) 166-171. 